\begin{tabular}{|c|c|c|c|c|}
\hline $\begin{array}{c}\text { Prosiding Penelitian \& } \\
\begin{array}{c}\text { Pengabdian Kepada } \\
\text { Masyarakat }\end{array}\end{array}$ & $\begin{array}{c}\text { e ISSN : 2581-1126 } \\
\text { p ISSN : 2442-448X }\end{array}$ & Vol 5, No: 2 & Hal: $158-164$ & Juli 2018 \\
\hline
\end{tabular}

\title{
FAKTOR PENDORONG IBU BEKERJA SEBAGAI K3L UNPAD
}

\author{
Julian Rizky, Meilanny Budiarti Santoso
}

Fakultas Ilmu Sosial Dan Ilmu Politik Universitas Padjadjaran

jrizky999@gmail.com; meilannybudiarti13@gmail.com

\begin{abstract}
Abstrak
Sudah sepatutnya seorang ibu mengurusi berbagai hal yang berhubungan dengan urusan rumah tangga. Hal ini merupakan salah satu dari sekian banyak tugas serta peran seorang ibu. Dewasa ini peran ibu bertambah intensitasnya sehingga peran dan tugas ibu menjadi semakin kompleks. Hal ini tidak terlepas dari banyaknya ibu yang sekarang ikut terjun ke dalam dunia kerja. Ibu bekerja identik dengan asumsi bahwa keluarga mengalami kekurangan. Belum lagi banyak problematika yang timbul akibat ibu bekerja. namun tidak sedikit juga ibu bekerja sebagai bentuk pengaplikasian atas ilmunya. Selalu adanya keterlibatan dan keterhubungan setiap aspek kehidupan dalam fenomena ibu bekerja. Terkait hal tersebut terdapat berbagai faktor yang mendorong mengapa akhirnya ibu bekerja, mulai dari faktor internal sampai eksternal. Faktor ini menciptakan berbagai dilema dan akhirnya menentukan apa dampak yang akan tercipta ketika ibu bekerja. Artikel ini bertujuan untuk menentukan faktor apa saja yang mendorong ibu bekerja. Hal tersebut menjadi sebuah dasar terhadap dinamika apa saja yang tercipta akibat ibu bekerja dan apa pengaruhnya terhadap kehidupan ibu maupun keluarga.
\end{abstract}

Kata kunci : Ibu bekerja, fungsi ibu

\begin{abstract}
It is a mothers job to do many things that are connected to the household. This is one of the many things a mother does. In this century the intensity in a mothers role and the duties of a mother makes her role more complex. This doesn't change the fact that lots of mothers are also working. Mothers that work are identical with the assumption that a family has many flaws. There are also lots of problematics that show up when a mother works. But there are lots of mothers that work as an application for their knowledge. There is always an involvement and connections on every aspect in the phenomenal life of a working mother. On that note there are also lots of factors that make mothers work, starting from internal to external factors. These factors create lots of dilemmas and finally decided what side effects will be created when mothers work. This article is to decide on what factors that push mothers to work. Those things became the basr to whatever dinamic that will be created from a working mother and what is the side effects to the mother and the family.
\end{abstract}

Keywords : working mothers, mothers function

\section{PENDAHULUAN}

Dahulu kaum perempuan lazimnya berperan sebagai istri dan seorang ibu dalam menjalankan perannya di dalam rumah tangga. Mengurus anak, mendidik anak, dan mengerjakan pekerjaan rumah tangga selalu melekat pada konteks seorang ibu. Paham ini masih terus berlaku khususnya di daerah pedesaan. Bahkan pada masa penjajahan seorang wanita dilarang untuk dapat mengenyam pendidikan sehingga memperkuat label bahwa wanita hanya akan menjadi sebatas mengerjakan pekerjaan rumah tangga saja. Seiring berjalannya waktu, akibat dari adanya modernisasi peran ibu pun sekarang bertambah intensitasnya. Peran ibu sekarang tidak hanya sebatas mengerjakan pekerjaan rumah, melainkan dapat sebagai pencari nafkah juga. Tidak sedikit yang menjadikan peran ibu dalam pemenuhan kebutuhan ekonomi menjadi sebuah keharusan akibat dari adanya desakan kebutuhan ekonomi yang 


\begin{tabular}{|c|c|c|c|c|}
\hline $\begin{array}{c}\text { Prosiding Penelitian \& } \\
\begin{array}{c}\text { Pengabdian Kepada } \\
\text { Masyarakat }\end{array}\end{array}$ & $\begin{array}{c}\text { e ISSN : 2581-1126 } \\
\text { p ISSN : 2442-448X }\end{array}$ & Vol 5, No: 2 & Hal: $158-164$ & Juli 2018 \\
\hline
\end{tabular}

menjerat. Pendapatan sang pencari nafkah utama yaitu suami yang tidak sebanding dengan kebutuhan rumah tangga mendorong ibu harus proaktif dalam ikut memberikan sumbangsihnya terhadap perekonomian keluarga. Hal ini terjadi pada keluarga dengan tingkat perekonomian rendah yang akhirnya membuat ibu maupun anggota keluarga lain untuk ikut bekerja demi meningkatkan pendapatan keluarga. Tidak hanya dari keluarga yang berpenghasilan rendah, banyak juga ibu dari kalangan keluarga menengah ke atas yang ikut terjun ke dalam dunia kerja.

Hal ini tidak terlepas dari adanya berbagai faktor yang mendorong ibu untuk bekerja. Berdasarkan penelitian yang dilakukan oleh Nilakusmawati (2009) menyebutkan alasan wanita bekerja pada sektor informal adalah dikarenakan faktor keharusan bekerja untuk dapat mengatasi kesulitan ekonomi rumah tangga. Alasan ini disampaikan oleh sekitar 86,0 persen responden penelitian, sedangkan untuk alasan responden mengenai aktualisasi diri, mencari afiliasi diri wadah untuk bersosialisasi merupakan alasan yang dijawab oleh 11,3 persen responden, dan alasan lainnya hanya sekitar 2,7 persen. Faktor desakan ekonomi masih menjadi faktor dominan yang membuat para ibu bekerja. Adapula faktor-faktor lain yang menyebabkan ibu bekerja seperti yang dikemukakan oleh Hernamawarni (2009) berdasarkan penelitiannya. Faktor-faktor tersebut yaitu seagai upaya dalam meningkatkan kualitas hidup, usaha dalam membayar hutang, adanya upaya untuk mengurangi ketergantungan terhadap suami dan meningkatkan status sosial atau prestise.

\section{Ibu Bekerja}

\section{Pengertian Ibu}

Menurut Kamus Besar Bahasa Indonesia mengenai ibu adalah seorang wanita yang telah/sudah melahirkan anak, maka anak harus menyayangi ibunya. Sebutan wanita yang sudah bersuami. Menurut Santoso dalam Farid (2016) ibu adalah seseorang yang memiliki banyak peran, peran sebagai istri, sebagai ibu dari anak-anaknya, dan sebagai seseorang yang melahirkan dan merawat anak-anaknya. Bagi anak-anaknya, ibu merupakan sebuah benteng bagi keluarga dimana ibu dapat menguatkan setiap anggota keluarga yang ada.

\section{Pengertian bekerja}

Menurut Undang-undang No. 13 tentang ketenagakerjaan, ketenagakerjaan adalah segala hal yang berhubungan dengan tenaga kerja pada waktu sebelum, selama, dan sesudah masa kerja.
Sedangkan tenaga kerja adalah setiap orang yang mampu melakukan pekerjaan guna menghasilkan barang dan/atau jasa baik untuk memenuhi kebutuhan sendiri maupun masyarakat. Menurut Mantra (2004) dalam Nilakusmawati (2009), bekerja memiliki pengertian yaitu suatu kegiatan untuk menghasilkan atau membantu menghasilkan barang atau jasa dengan maksud untuk memperoleh penghasilan berupa uang dan atau barang, dalam kurun waktu (time reference) tertentu. Sedangkan menurut Alwi (dalam Nurhidayah, 2008: 3) bekerja adalah kegiatan melakukan sesuatu untuk mencari nafkah atau sebagai mata pencaharian. Jadi bekerja adalah sebuah aktivitas yang dilakukan oleh seseorang terkait suatu bentuk mata pencaharian dan upaya untuk mendapatkan balas jasa berupa penghasilan.

\section{Konsep Ibu Bekerja}

Martlin (1987) dalam Nilakusmawati (2009) menggunakan istilah working mothers, yang mengacu kepada dua pengertian, yaitu wanita yang bekerja di luar rumah yang memperoleh penghasilan sebagai imbalan dari bekerja dan wanita yang tidak memperoleh penghasilan karena bekerja di dalam rumah. Matlin menemukan secara khusus mengenai wanita yang bekerja di luar rumah dan memperoleh penghasilan dari hasil bekerjanya sebagai employed women. Pandia (1997) menyatakan bahwa wanita bekerja (employed woman) adalah wanita yang bekerja di luar rumah dan menerima uang atau memperoleh penghasilan dari hasil pekerjaannya. Menurut Vureen (dalam Mufidah, 2009), ibu yang bekerja adalah ibu yang selain mengurus rumah tangga juga memiliki tanggung jawab di luar rumah baik di kantor, yayasan, atau wiraswasta dengan kisaran waktu 6 sampai 8 jam sehari. Menurut Agustine Sukarlan Basri salah satu staf pengajar Jurusan Psikologi Klinis Universitas Indonesia (dalam Nurhidayah, 2008: 3) mengatakan kecenderungan para ibu jaman sekarang memilih kembali bekerja setelah punya anak bukan semata-mata mereka senang bekerja.

\section{Alasan Ibu Bekerja}

Munandar (dalam Pandia, 1997) menyatakan bahwa ada beberapa alasan yang membuat seorang ibu bekerja antara lain yaitu untuk menambah penghasilan dan pendapatan, upaya untuk menghindari rasa bosan atau jenuh dalam mengisi waktu kosong atau luang, menyalurkan minat atau keahlian tertentu, mencapai status tertentu, dan untuk sebagai upaya pengembangan diri. Menurut pendapat Ware (1981) dalam Ken Suratiyah, et. al (1996) 


\begin{tabular}{|c|c|c|c|c|}
\hline $\begin{array}{c}\text { Prosiding Penelitian \& } \\
\begin{array}{c}\text { Pengabdian Kepada } \\
\text { Masyarakat }\end{array}\end{array}$ & $\begin{array}{c}\text { e ISSN : 2581-1126 } \\
\text { p ISSN : 2442-448X }\end{array}$ & Vol 5, No: 2 & Hal: $158-164$ & Juli 2018 \\
\hline
\end{tabular}

Menyatakan bahwa setidaknya ada dua alasan utama yang melatarbelakangi keterlibatan perempuan dalam pasar kerja. Pertama, adalah sebuah keharusan sebagai refleksi dari kondisi ekonomi rumah tangga yang rendah, sehingga bekerja untuk meningkatkan pendapatan rumah tangga menjadi sesuatu yang penting. Kedua, "memilih" untuk bekerja, sebagai refleksi dari kondisi sosial ekonomi pada tingkat menengah ke atas. Bekerja bukan hanya semata-mata berorientasi pada mencari tambahan pemasukan untuk menyokong ekonomi keluarga melainkan salah satu bentuk aktualisasi diri, mencari afiliasi diri dan sebagai wadah untuk bersosialisasi. (Nurhidayah, 2008: 3) menyatakan bahwa alasan utama yang melandasi latar belakang tindakan para ibu untuk bekerja ada beberapa faktor yaitu kebutuhan finansial, kebutuhan sosial-relasional, dan kebutuhan aktualisasi diri.

\section{Manfaat Ibu Bekerja}

Terlepas dari dampak negatif yang ditimbulkan akibat ibu bekerja, tidak sedikit juga manfaat dari adanya ibu bekerja dalam keluarga seperti yang diungkapkan Jacinta F. (dalam Nurhidayah, 2008: 4) bahwa terdapat beberapa segi positif dari ibu bekerja yaitu mendukung ekonomi keluarga dalam hal pemenuhan finansial, meningkatnya harga diri dan pemantapan identitas, relasi yang sehat dan positif dengan keluarga, dan meningkatnya keahlian dan kemampuan yang dilakukan secara terus-menerus akan mendatangkan nilai tambah pada diri seorang karyawan.

\section{Pengertian K3L}

K3L adalah kepanjangan dari Kebersihan, Keindahan, dan Kenyamanan Lingkungan. K3L Unpad merupakan suatu bentuk aksi sosial yang dicanangkan oleh pindah Unpad untuk memberdayakan warga yang tinggal di sekitar Jatinangor. Tenaga K3L Unpad tidak bersifat outsourcing dikarenakan pihak Unpad yang mengatur sistem K3L melalui sarana dan prasarana Unpad. K3L Unpad memiliki fungsi untuk menciptakan lingkungan yang bersih, asri, dan nyaman bagi civitas Unpad. Beberapa tugas dari K3L Unpad diantaranya membersihkan sampah di area sekitar Unpad, merawat taman-taman yang ada di wilayah Unpad, agen pemeliharaan kebersihan di Unpad, dan memotong rumput liar di sekitaran Unpad. Setiap tugas tersebut memiliki SOP-nya tersendiri.

\section{METODE}

\section{Penelitian dan jenis pendekatan}

Penelitian ini adalah penelitian deskriptif analitik. Whitney dalam Moh. Nazir menyatakan bahwa metode deskriptif adalah pencarian fakta dengan interpretasi yang tepat. Penelitian deskriptif mempelajari segala masalah yang ada di dalam masyarakat dan tata cara yang berlaku dalam masyarakat serta situasi-situasi tertentu, termasuk tentang kegiatan-kegiatan, hubungan hubungan, pandangan-pandangan, sikap-sikap, serta prosesproses yang sedang berlangsung dan pengaruhpengaruh dari suatu fenomena. Dalam hal ini fenomena yang dimaksud adalah fenomena faktor pendorong ibu bekerja sebagai K3L Unpad. Penelitian ini menggunakan gabungan antara pendekatan kualitatif dan kuantitatif. pendekatan kualitatif yaitu data yang dikumpulkan bukan berupa angka-angka, melainkan data tersebut berasal dari naskah wawancara dan catatan lapangan. Menurut Keirl dan Miller dalam Moleong yang dimaksud dengan penelitian kualitatif adalah tradisi tertentu dalam ilmu pengetahuan sosial yang secara fundamental bergantung pada pengamatan, manusia, kawasannya sendiri, dan berhubungan dengan orang-orang tersebut dalam bahasanya dan peristilahannya. Penelitian ini juga menggunakan pendekatan kuantitatif dimana data yang diperoleh berupa angka-angka. Data ini berasal dari tabel kuesioner terhadap K3L Unpad untuk mendapatkan data tentang fenomena faktor pendorong ibu bekerja sebagai K3L Unpad untuk menjadi data penyokong dalam penelitian ini.

\section{Data dan sumber data}

Penelitian ini menggunakan gabungan dari data primer dan data sekunder. Data primer menurut Nasution (1964) adalah data yang dapat diperoleh langsung dari lapangan atau tempat penelitian. Dalam hal ini informasi yang saya dapat dari narasumber melalui wawancara terkait faktor yang mendorong ibu bekerja sebagai K3L merupakan data primer dari penelitian ini. Data sekunder adalah data yang diperoleh dengan studi literatur dan pemahaman secara konseptual berdasarkan referensi yang di dapat. Data sekunder dapat berasal dari jurnal, artikel majalah, buletin, ataupun publikasi dari berbagai organisasi, hasilhasil studi, hasil survei, dan sebagainya. Data sekunder ini bertujuan untuk memperkuat dan melengkapi informasi yang telah dikumpulkan.

\section{PEMBAHASAN}

Tabel 1

Sumber : penelitian 2018 


\begin{tabular}{|c|c|c|c|c|}
\hline $\begin{array}{c}\text { Prosiding Penelitian \& } \\
\begin{array}{c}\text { Pengabdian Kepada } \\
\text { Masyarakat }\end{array}\end{array}$ & $\begin{array}{c}\text { e ISSN : 2581-1126 } \\
\text { p ISSN : 2442-448X }\end{array}$ & Vol 5, No: 2 & Hal: $158-164$ & Juli 2018 \\
\hline
\end{tabular}

Tabel 2

\begin{tabular}{|c|c|c|c|}
\hline Nbo & JeniłsmKelamin & $\mathrm{F} F$ & $\% / \%$ \\
\hline $1^{1}$ & ptetemtouran & 07 & $09 \% \%$ \\
\hline 2 & $20-24$ & 1 & $11 \%$ \\
\hline 23 & 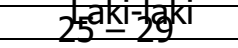 & 02 & $0 \% \%$ \\
\hline 4 & JußPPah 34 & 19 & $11100 \%$ \\
\hline 5 & $>34$ & 7 & $78 \%$ \\
\hline \multicolumn{2}{|c|}{ Jumlah } & 9 & $100 \%$ \\
\hline
\end{tabular}

Sumber : penelitian 2018

Berdasarkan data kuesioner mengenai pekerja K3L Unpad terdapat 9 responden yang menjadi sampel dalam data tersebut untuk mewakili setiap zona yang ada di Unpad dan pada penelitian ini termasuk ke dalam zona 8. 78 persen pekerja K3L Unpad pada zona 8 merupakan perempuan artinya terdapat 7 dari 9 orang pekerja K3L ini merupakan perempuan. Jika dilihat berdasarkan umur, 78 persen merupakan para pekerja K3L yang berumur $>34$ tahun, lalu 11 persen berumur antara 20 sampai 24 dan 11 persen berumur antara 30 sampai 34 tahun. Bisa dilihat pada tabel 1 dan 2 .

Adanya keterkaitan antara jenis kelamin yang didukung oleh suatu umur tertentu menjadi salah satu faktor pendorong dari ibu untuk bekerja sebagai K3L Unpad. Menurut Ibu Yati, yaitu salah satu narasumber dari penelitian ini menyebutkan bahwa pekerjaan K3L ini menjadi pilihannya untuk bekerja dikarenakan beliau merasa bahwa pekerjaan $\mathrm{K} 3 \mathrm{~L}$ identik dengan pekerjaan yang dilakukan oleh perempuan. Hal-hal seperti membersihkan taman, membersihkan gedung, dan sebagainya dirasa lebih cocok dikerjakan oleh perempuan dibanding oleh laki-laki. Kebiasaan para ibu membereskan segala pekerjaan rumah menjadi sebuah modal dalam bekerja sebagai K3L dan memperkuat alasan bahwa pekerjaan K3L merupakan pekerjaan yang sesuai dengan kondisi mereka. Pekerjaan K3L tidak membutuhkan skill khusus, tapi yang dibutuhkan hanya ketelatenan dimana hal itu sudah biasa dilakukan oleh beliau dan ibu-ibu lainnya yang sudah berumur lebih dari 34 tahun atau dewasa dikarenakan hal tersebut sudah menjadi salah satu tugasnya dalam keluarga. Keterkaitan antara jenis kelamin dengan umur ini juga mengakibatkan seseorang akhirnya ketika bekerja harus memilih pekerjaan dengan jam kerja yang tepat. Seperti yang menjadi alasan mengapa akhirnya Ibu Yati bekerja sebagai K3L dikarenakan beliau ingin bekerja tapi yang sekiranya beliau juga masih dapat meluangkan waktu untuk dapat mengurusi pekerjaan rumah dan anak. Sebelum menjadi pekerja K3L beliau sempat menjadi buruh dimana jam kerja sebagai buruh sangat menyita waktunya sehingga akhirnya beliau keluar dari pekerjaan tersebut. Jam kerja yang ditawarkan oleh pekerjaan ini cukup strategis yaitu dimulai dari pukul 6 pagi hingga 12 siang sehingga menjadi tambahan daya tarik bagi para ibu yang bekerja sebagai K3L ini. Para ibu ini selain bekerja, mereka juga harus tetap mengurus anaknya terlebih khususnya seperti di daerah perkampungan dimana tidak ada yang memakai jasa pengasuh anak seperti di perkotaan sehingga jam kerja yang ditawarkan menjadi sesuatu yang strategis untuk para ibu agar dapat mengurus anak sekaligus bekerja demi menambah penghasilan keluarga.

Tabel 3

\begin{tabular}{|c|c|c|c|}
\hline No & Status Perkawinan & $\mathrm{F}$ & $\%$ \\
\hline 1 & Belum Kawin & 1 & $11 \%$ \\
\hline 2 & Kawin & 5 & $56 \%$ \\
\hline 3 & Janda/Duda & 3 & $33 \%$ \\
\hline \multicolumn{2}{|c|}{ Jumlah } & 9 & $100 \%$ \\
\hline
\end{tabular}

Sumber : penelitian 2018

Tabel 4

\begin{tabular}{|l|l|l|l|}
\hline No & Kedudukan Dalam Keluarga & $\mathrm{F}$ & $\%$ \\
\hline 1 & Kepala Keluarga & 4 & $44 \%$ \\
\hline 2 & Istri & 4 & $44 \%$ \\
\hline 3 & Anak & 1 & $12 \%$ \\
\hline Jumlah & 9 & $100 \%$ \\
\hline
\end{tabular}

Sumber : penelitian 2018

Tabel 5

\begin{tabular}{|l|l|l|l|}
\hline No & $\begin{array}{l}\text { Anggota Keluarga Lain Yang } \\
\text { Mencari Nafkah }\end{array}$ & F & $\%$ \\
\hline 1 & Ada & 7 & $78 \%$ \\
\hline 2 & Tidak Ada & 2 & $22 \%$ \\
\hline \multicolumn{2}{|l}{ Jumlah } & 9 & $100 \%$ \\
\hline
\end{tabular}

Sumber : penelitian 2018

Presentase pekerja K3L berdasarkan status perkawinan menunjukkan bahwa untuk pekerja K3L yang sudah kawin sebesar 56 persen dari 9 responden, diikuti oleh yang janda atau duda sebesar 33 persen dan 11 persen untuk pekerja yang belum kawin. Pekerja K3L yang berkedudukan sebagai kepala keluarga sebesar 44 persen yang terdiri dari 2 laki-laki dan 2 perempuan (janda) lalu yang berkedudukan sebagai istri sebesar 44 persen dan seorang satu orang berkedudukan sebagai anak dengan presentase sebesar 12 persen. Presentase berdasarkan adanya anggota keluarga lain yang mencari nafkah menunjukkan sebesar 78 persen menyatakan bahwa ada anggota keluarga lain yang mencari nafkah selain kepala keluarga yang artinya terdapat 7 dari 9 responden 


\begin{tabular}{|c|c|c|c|c|}
\hline $\begin{array}{c}\text { Prosiding Penelitian \& } \\
\begin{array}{c}\text { Pengabdian Kepada } \\
\text { Masyarakat }\end{array}\end{array}$ & $\begin{array}{c}\text { e ISSN : 2581-1126 } \\
\text { p ISSN : 2442-448X }\end{array}$ & Vol 5, No: 2 & Hal: $158-164$ & Juli 2018 \\
\hline
\end{tabular}

menyatakan ada dan 22 persen menyatakan tidak ada. Lihat tabel 7. Hal ini menunjukkan bahwa sebagian besar sudah berkelurga dan memilih untuk menjadi K3L. Lihat tabel 3, 4, dan 5.

Faktor perkawinan menjadi salah satu faktor yang mendorong ibu bekerja sebagai K3L. Bila melihat dari definisi ibu sesuai dengan konseptual, artinya dengan adanya perkawinan berarti muncul sebuah tanggung jawab dan tanggungan contohnya berupa kebutuhan ekonomi. Tanggung jawab berupa kebutuhan ekonomi ini membuat para suami harus menjalankan tugasnya untuk mencari nafkah namun pada kenyataannya pendapatan suami tidak dapat menutup pengeluaran dari keluarga. Hal ini membuat para ibu akhirnya ikut turun tangan dalam mencari nafkah. Menurut Ibu Yati pendapatan hanya dari suami saja tidak cukup untuk dapat menghidupi beliau dan anak-anaknya sehingga akhirnya beliau ikut bekerja.

Tabel 6

\begin{tabular}{|c|c|c|c|}
\hline No & Pendidikan Terakhir & $\mathrm{F}$ & $\%$ \\
\hline 1 & SD/Sederajat & 1 & $89 \%$ \\
\hline 2 & SMP/Sederajat & 5 & $0 \%$ \\
\hline 3 & SMA/Sederajat & 3 & $0 \%$ \\
\hline 4 & Perguruan Tinggi & 1 & $11 \%$ \\
\hline \multicolumn{2}{|r|}{ Jumlah } & 9 & $100 \%$ \\
\hline
\end{tabular}

Presentase pekerja K3L berdasarkan pendidikan terakhir menunjukkan 89 persen pekerja K3L merupakan lulusan SD atau sederajat artinya 8 dari 9 orang pekerja K3L tersebut hanya sebatas lulusan SD atau sederajat dan 1 orang yang memiliki tingkat pendidikan terakhir lulusan perguruan tinggi. Pendidikan yang rendah menyebabkan kemampuan seseorang menjadi terasa terbatas. Setiap pekerjaan memiliki spesifikasi pelamar dengan tingkat pendidikan tertentu, namun beda halnya dengan menjadi K3L di Unpad. Dikarenakan program K3L ini merupakan sebuah bentuk aksi sosial dari pihak Unpad guna memberdayakan masyarakat di sekitaran Jatinangor yang kurang beruntung maka latarbelakang pendidikan hanya menjadi sebuah formalitas belaka. Terlebih lagi para ibu di sekitaran Jatinangor hanya berpendidikan lulusan SD seperti yang dialami oleh Ibu Yati. Ibu Yati mengungkapkan bahwa status pendidikannya yang rendah membuatnya sulit dan merasa tidak percaya diri untuk mendapatkan pekerjaan yang layak. Adanya fleksibilitas terkait latarbelakang pendidikan untuk menjadi pekerja K3L dari pihak Unpad menjadi dorongan bagi Ibu Yati dan para ibu lainnya untuk bekerja sebagai K3L. Biasanya pendidikan menjadi syarat utama dalam setiap melamar pekerjaan setelah kemampuan dan pengalaman sehingga akhirnya membuat beliau memilih untuk menjadi $\mathrm{K} 3 \mathrm{~L}$ Unpad dengan alasan pendidikan yang rendah. Keresahan yang selama ini dirasakan oleh Ibu Yati setiap kali melamar kerja akhirnya dapat terjawab dengan adanya fleksibilitas dari sistem rekruitmen yang ditawarkan pekerjaan ini. Maka dapat dikatakan bahwa status pendidikan menjadi salah satu faktor yang mendorong ibu untuk bekerja sebagai K3L. Tingkat pendidikan yang tinggi akan berbanding lurus dengan tingkat pekerjaan yang semakin layak begitu pula sebaliknya dengan tingkat pendidikan yang rendah akan semakin sulit untuk mendapatkan pekerjaan yang layak dikarenakan pendidikan menjadi modal bagi setiap pekerjaan khususnya pekerjaan dengan spesialisasi kemampuan tertentu.

Tabel 7

\begin{tabular}{|c|c|c|c|}
\hline No & $\begin{array}{c}\text { Tujuan Bekerja sebagai } \\
\text { K3L Unpad }\end{array}$ & $F$ & $\%$ \\
\hline 1 & $\begin{array}{l}\text { Mendapatkan sumber } \\
\text { penghasilan pertama }\end{array}$ & 4 & $44 \%$ \\
\hline 2 & $\begin{array}{c}\text { Menambah penghasilan } \\
\text { keluarga }\end{array}$ & 5 & $56 \%$ \\
\hline \multicolumn{2}{|r|}{ Jumlah } & 9 & $100 \%$ \\
\hline
\end{tabular}

Presentase pekerja K3L berdasarkan tujuan bekerja sebagai K3L Unpad menunjukkan bahwa sebesar 56 persen beralasan demi menambah penghasilan keluarga dan 44 persen menjadikan pekerjaan K3L sebagai sumber penghasilan utama. Sesuai dengan konsep bahwa dorongan terbesar ibu bekerja adalah dari adanya faktor ekonomi. Berdasarkan alasan ekonomi ini dapat bersinggungan dengan aspek kehidupan lain seperti pendidikan, kesehatan, gaya hidup, dan sebagainya. Ketika kekuatan finansial dalam keluarganya rendah maka hal ini akan sangat berpengaruh terhadap aspek kehidupan yang lain karena hidup bukan hanya soal memenuhi kebutuhan pangan saja. Tingkat ekonomi yang rendah dapat mempengaruhi tingkat kesehatan menjadi rendah juga atau sebaliknya. Aspek ekonomi dalam sebuah keluarga menjadi sebuah dinamika tersendiri sehingga akhirnya mendorong seseorang untuk bekerja. Faktor ekonomi menjadi kebanyakan alasan yang mendasari ibu akhirnya beralih dari yang tadinya seorang ibu rumah tangga menjadi ibu bekerja. Terjadilah peningkatan intensitas peran yang dialami oleh ibu. Hal ini juga dipengaruhi oleh penghasilan suami. Jika dilihat dari tabel diatas, dominan beralasan untuk menambah 


\begin{tabular}{|c|c|c|c|c|}
\hline $\begin{array}{c}\text { Prosiding Penelitian \& } \\
\begin{array}{c}\text { Pengabdian Kepada } \\
\text { Masyarakat }\end{array}\end{array}$ & $\begin{array}{c}\text { e ISSN : 2581-1126 } \\
\text { p ISSN : 2442-448X }\end{array}$ & Vol 5, No: 2 & Hal: $158-164$ & Juli 2018 \\
\hline
\end{tabular}

penghasilan keluarga. Artinya dengan adanya alasan ibu bekerja untuk menambah penghasilan keluarga berarti terlihat pula adanya kekurangan pendapatan yang dihasilkan suami. Penghasilan suami menentukan seberapa besar dorongan ibu untuk akhirnya memutuskan ikut bekerja. Adanya gap yang besar dari pendapatan keluarga terhadap pengeluaran membuat banyak dari ibu untuk akhirnya memutuskan untuk bekerja, belum lagi jika adanya desakan hutang. Sehingga memperkuat dorongan untuk ikut bekerja dengan asumsi membantu suami. Berdasarkan wawancara saya terhadap Ibu Yati, suami beliau memiliki penghasilan yang tidak seberapa, belum lagi Ibu Yati memiliki upaya untuk menyekolahkan anaknya setinggi mungkin dan sekarang anak sulung dari Ibu Yati sudah hampir menamatkan jenjang SMA sehingga ini menjadi bagian dari dorongan Ibu Yati untuk bekerja sebagai K3L. Ikut bekerjanya seorang ibu selalu identik dengan kondisi ekonomi yang kurang mampu atau sulit. Adapula ibu yang beralasan bekerja sebagai $\mathrm{K} 3 \mathrm{~L}$ dengan alasan yang bukan karena keluarganya tidak mampu ataupun ia benar-benar membutuhkan pekerjaan akibat terdesak namun dikarenakan hanya sekedar ingin membantu suami padahal sebenarnya secara finansial keluarga mereka cukup-cukup saja. Kondisi yang seperti ini biasanya dialami oleh seorang ibu yang tidak berada dalam desakan ekonomi melainkan hanya sebatas untuk mengaktualisasikan diri dengan lingkungan sosial. Biasanya keadaan jenuh mendorong ibu untuk ikut bekerja demi mencari suasana yang berbeda dan menjalin hubungan sosial yang lebih luas.

Adapula yang menjadikan alasan bekerja menjadi pekerja K3L ini sebagai pekerjaan utama. Jika poin pada tabel ini dihubungkan dengan tabel 1 dan 3 maka setidaknya ada 1 orang ibu yang merupakan seorang janda yang menjadikan pekerjaan K3L ini sebagai pekerjaan utama. Desakan serta tuntutan hidup akibat status seorang janda ini mengharuskan ibu untuk bekerja sebagai K3L demi dapat menghidupi dirinya dan keluarganya. Tidak ada alasan untuk tidak bekerja. Kemudahan untuk bisa bekerja menjadi K3L Unpad ini mendorong ibu bekerja sebagai K3L Unpad. Hal ini tidak terlepas dari adanya beberapa faktor dan kondisi yang sudah disebutkan sebelumnya bahwa latarbelakang pendidikan yang rendah memaksa para ibu maupun pekerja K3L ini menjadikan pekerjaan K3L sebagai penghasilan utama. Adanya dilema ketika ingin bekerja dengan pekerjaan yang layak dan berpenghasilan tinggi namun tidak ditunjang dengan tingkat pendidikan yang tinggi dan kemampuan yang mumpuni.
Selanjutnya yang menjadi faktor pendorong ibu bekerja sebagai pekerja K3L adalah adanya saran dan dorongan dari pihak lain. Para pekerja K3L Unpad kebanyakan adalah para warga yang tinggal di sekitaran wilayah Unpad dimana daerah ini masih banyak yang berbentuk desa atau perkampungan. $\mathrm{Di}$ desa masih sangat erat sosialisasi antar tetangga dan kerukunan yang terjalin masih sangat baik. Banyak kebiasaan di desa yang membuat orang satu dengan orang yang lainnya bertemu tatap muka. Interaksi di desa masih terbilang cukup besar intensitasnya dan dilakukan secara konvensional. Kondisi ini sering kali digunakan untuk ajang pertukaran informasi. Banyak pekerja K3L Unpad yang mengetahui info lowongan pekerjaan menjadi pekerja $\mathrm{K} 3 \mathrm{~L}$ dari mulut ke mulut. Pesan mulut ke mulut ini masih terbilang efektif terjadi di desa. Pesan yang disampaikan oleh orang terdekat biasanya lebih bisa dipercaya terlebih lagi jika pesan tersebut mengandung unsur persuasif sehingga tercipta dorongan untuk bekerja sebagai pekerja K3L Tidak jarang ketika K3L merasa kekurangan pekerja maka pihak atasan terkadang meminta para pekerja untuk menawarkan lowongan tersebut sehingga. Biasanya jaringan sosial yang dimiliki oleh ibu rumah tangga di desa terbilang tinggi sehingga memungkin untuk akhirnya ibu akhirnya terdorong untuk bekerja.

Ketika ibu bekerja banyak dampak yang terjadi baik kepada diri ibu sendiri maupun keluarga. Pemilihan pekerjaan yang tepat dapat meminimalisir dampak negatif yang terjadi dan menciptakan berbagai dampak positif yang sangat menguntungkan bagi diri ibu dan keluarga. Berbagai faktor pendorong tersebut juga mempengaruhi ibu dalam mengambil keputusan dalam penentuan pekerjaan. Sama halnya seperti ketika ibu bekerja sebagai pekerja K3L terlepas dari tujuan untuk mendapatkan pendapatan. Sebagai pekerja K3L dengan jam kerja hanya sampai jam 12 sebenarnya hal tersebut tidak benar-benar menyita waktu seperti pekerjaan lain untuk seorang ibu agar dapat melakukan tugasnya sebagai ibu rumah tangga. Ibu masih sangat bisa untuk mengatur mana porsi untuk bekerja dan porsi untuk mengurusi urusan rumah tangga. Ketika ibu bekerja ada dampak stres yang timbul akibat berbagai dinamika dan persoalan di tempat kerja. Stres ini dapat mempengaruhi bagaimana peran ibu di rumah. Ibu yang seharusnya sebagai pusat kontrol emosi keluarga namun apabila dalam keadaan stres maka ibu tidak bisa menjadi penyeimbang anggota keluarga yang lainnya.

\section{Kesimpulan dan Saran}




\begin{tabular}{|c|c|c|c|c|}
\hline $\begin{array}{c}\text { Prosiding Penelitian \& } \\
\begin{array}{c}\text { Pengabdian Kepada } \\
\text { Masyarakat }\end{array}\end{array}$ & $\begin{array}{c}\text { e ISSN : 2581-1126 } \\
\text { p ISSN : 2442-448X }\end{array}$ & Vol 5, No: 2 & Hal: $158-164$ & Juli 2018 \\
\hline
\end{tabular}

Berdasarkan pemaparan diatas maka dapat disimpulkan bahwa ibu bekerja memiliki berbagai faktor yang mendorong tergantung bagaimana situasi dan kondisi yang dihadapinya. Faktor ekonomi selalu menjadi faktor utama yang mempengaruhi keputusan seorang ibu bekerja. Dalam fenomena ibu bekerja sebagai K3L Unpad ini faktor ekonomi menjadi alasan utama bagi para ibu. Kondisi ekonomi yang kurang mampu menjadi faktor pendorong yang kuat bagi para ibu untuk akhirnya memutuskan ikut bekerja dan menambah perannya di dalam keluarga. Walaupun pekerjaan tersebut masih jauh dari kata layak namun berbagai faktor pendorong lainnya memperkuat dorongan ibu untuk bekerja sebagai pekerja K3L. Diantaranya terkait alasan hubungan antara tingkat pendidikan dengan kesempatan kerja. Tingkat pendidikan yang rendah dari para ibu yang tinggal di daerah sekitaran Jatinangor ini membuat para ibu akhirnya memilih untuk bekerja sebagai pekerja K3L karena adanya fleksibilitas yang ditawarkan oleh pihak Unpad mengenai tidak terlalu diperhatikannya latarbelakang pendidikan yaitu syarat minimal lulusan SD atau sederajat. Selain kedua alasan tersebut terdapat berbagai alasan lain yang mendorong ibu bekerja sebagai pekerja K3L Unpad baik faktor internal maupun eksternal.

Diharapkan artikel ini mampu mengembangkan baik secara konseptual maupun data yang diambil sebagai penelitian. Pematangan secara konsep dapat diimbangi dengan pengumpulan data yang lebih baik lagi guna mendapatkan informasi yang lebih akurat sehingga dapat tersampaikan dengan baik.

\section{DAFTAR PUSTAKA}

Apreviadizy P, dkk. 2014. Perbedaan Stress Ditinjau Dari Ibu Bekerja Dan Ibu Tidak Bekerja. Jurnal Psikologi Tabularasa. 9(1): 58-65.

Baharun, H. 2016. Pendidikan Anak Dalam Keluarga; Telaah Epistemologis. Pedagogik; Jurnal Pendidikan. 3(2): 96-107.
Briawan D, dkk. 2008. Peran Stimulasi Orangtua Terhadap Perkembangan Anak Balita Keluarga Miskin. 1(1): 64-76.

Horton, BP, dkk 1992. Sosiologi. Edisi keenam. (terj.) Jakarta: Penerbit Erlangga

Hyoscyamina, DE. 2011. Peran Keluarga Dalam Membangun Karakter Anak. Jurnal Psikologi Undip. 10(2): 144-152.

Nilakusmawati, dkk. 2012. Studi Faktor-Faktor Yang Mempengaruhi Wanita Bekerja Di Kota Denpasar. Piramida jurnal kependudukan dan pengembangan sumber daya manusia. 3(1): 26-31.

Nisfiannoor M, dkk. 2005. Perbandingan Perilaku Agresif Antara Remaja Yang Berasal Dari Keluarga Bercerai Dengan Keluarga Utuh. Jurnal Psikologi. 3(1): 1-18.

Nurhidayah, S. 2008. Pengaruh Ibu Bekerja Dan Peran Ayah Dalam Coparenting Terhadap Prestasi Belajar Anak. Jurnal Soul. 1(2): 1-14.

Purwaningsih, E. 2010. Keluarga Dalam Mewujudkan Pendidikan Nilai Sebagai Upaya Mengatasi Degradasi Moral. Jurnal Pendidikan Sosiologi Dan Humaniora. 1(1): 44-55.

Putri DF, dkk. 2012. Perbedaan Ibu Bekerja dan Ibu Rumah Tangga Terhadap Tumbuh Kembang Anak Usia 2-5 Tahun. Mutiara Medika. 12(3): 143-149.

Rakhmawati, I. 2015. Peran Keluarga Dalam Pengasuhan Anak. Jurnal Bimbingan Konseling Islam. 6(1): 1-18.

Soetomo. 2008. Masalah Sosial Dan Upaya Pemecahannya. Yogyakarta: Pustaka Pelajar.

Sudarsana, IK. 2017. Peranan Orangtua Dalam Penanaman Budi Pekerti Pada Anak. Institut Hindu Dharma Negeri. 157-160. 